\title{
APS sprayed coatings onto the selective laser melted substrates
}

\section{Powłoki APS natryskiwane na podłoża przetapiane wiązką laserową}

\section{Abstract}

Additive layer-based selective laser melting technologies (SLM), provide a new range of possibilities for objects manufacturing. In the present study the alumina/ titania $\mathrm{Al}_{2} \mathrm{O}_{3} / \mathrm{TiO}_{2}$ coatings were applied onto SLM-manufactured substrates by the atmospheric plasma spraying method. The microstructure and porosity of coatings were examined by scanning electron microscopy (SEM), and industrial computer tomography. Bonding strength of the coatings was analysed.

\section{Streszczenie}

Generatywne technologie selektywnego przetapiania laserowego (SLM) zapewniają nowe możliwości wytwarzania części maszyn. W pracy badaniom poddano powłoki tlenku glinu i tytanu $\mathrm{Al}_{2} \mathrm{O}_{3} / \mathrm{TiO}_{2}$ nanoszone za pomocą metody natryskiwania plazmowego APS na podłoża wykonane w procesie SLM. Przy zastosowaniu skaningowej mikroskopii elektronowej i przemysłowej tomografii komputerowej przeprowadzono ocenę mikrostruktury i porowatości powłok, jak również poddano analizie przyczepność powłok.

\section{Introduction}

Selective laser melting SLM is an additive manufacturing process based on the layered forming of physical objects by fusing of materials in the form of powder. This method allows processing for wide range of metal powders including stainless steels, tool steels, as well as $\mathrm{Cr}-\mathrm{Co}$ and Ti alloys. The SLM technology is the process of total metal powders melting using the controlled beam of $100 \mathrm{~W}$ (up to $400 \mathrm{~W}$ ), $1064 \mathrm{~nm}$ wave length, Nd:YAG fibre laser [1, 2]. The process of melting runs in the protective atmosphere of argon preventing against oxidation of the fused metal powders. Due to the layered incremental process of manufacturing and the wide range of available materials the technology could be applied for creating physical objects of complex geometrical structure both, internal and external. The SLM process finds application in manufacturing prototypes, final products [2], as well as tools, involving inserts of injection moulds [3] or stamping die parts.

Dr inż. Mariusz Frankiewicz, prof dr hab. inż. Edward Chlebus, mgr inż. Karol Kobiela - Politechnika Wrocławska.
Operating properties of objects manufactured using the selective laser melting method may be improved by applying additional surface engineering treatment such as the functional coating deposition.

One of the methods of improving properties of components manufactured in the SLM process is plasma spraying. In the plasma spraying processes the material in a form of powder is supplied to plasma gun (plasmatron), fused and then deposited onto a substrate surface with a velocity of approximately $150 \mathrm{~m} / \mathrm{s}$. Functional coatings deposited with this method may be, among others, characterised with: resistance to diffusion, low friction coefficient, resistance to low- and high-temperature corrosion in aggressive chemical environment, as well as high surface hardness and high wear resistance $[4,5]$.

The plasma-sprayed $\mathrm{Al}_{2} \mathrm{O}_{3} / \mathrm{TiO}_{2}$ coatings provide a high wear resistance properties, are applied among others, in the textile, machinebuilding and paper indu-

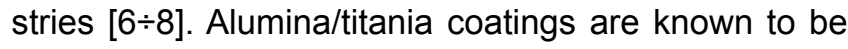
dense, with smooth as-sprayed surface. Alumina/titania with $3 \%$ share by weight of $\mathrm{TiO}_{2}(97 / 3)$ has been applied for preventing wear, as well as chemical and cavitational erosion in pump components [4]. Also, the variation of $\mathrm{Al}_{2} \mathrm{O}_{3} / \mathrm{TiO}_{2}$ composition with increased 
to $13 \%$ share by weight of $\mathrm{TiO}_{2}$ is used $\left(\mathrm{Al}_{2} \mathrm{O}_{3}-13 \%\right.$, $\mathrm{TiO}_{2}$ ). Increase in share of titanium dioxide improves the crack resistance [4]. For tests the material supplied by BayState Surface Tech designated as PP-37 $\left(\mathrm{Al}_{2} \mathrm{O}_{3}\right.$ $-3 \%, \mathrm{TiO}_{2}$ ) was used.

The research were aimed at initial analysis of coatings deposited by plasma spraying at substrates manufactured by the selective laser melting process. For that purpose the tests of surface profile, using confocal microscopy, industrial computer tomography and SEM were applied. The tests were performed with the purpose of evaluating the influence of substrate surface characteristics at the coating adhesion degree.

\section{Sample preparation}

The substrates were made of the Ti6Al7 Nb titanium alloy [1] by the SLM Realizer II system. Orientation of the analysed substrate surface during SLM manufacturing process has been presented in Fig. 1. The research was carried out on four sets of five samples each. Three sets were grit-blasted with three different energies of abrasive material stream each $\left(\mathrm{Al}_{2} \mathrm{O}_{3}\right.$ with grain size of $120 \mu \mathrm{m}$ ), related to the three values of aluminium oxide feeding pressure, presented in the Table I. One set of the samples was coated without additional machining of the substrate surface.

The first stage of the research was aimed on identification of the influence of the grit-blasting parameters

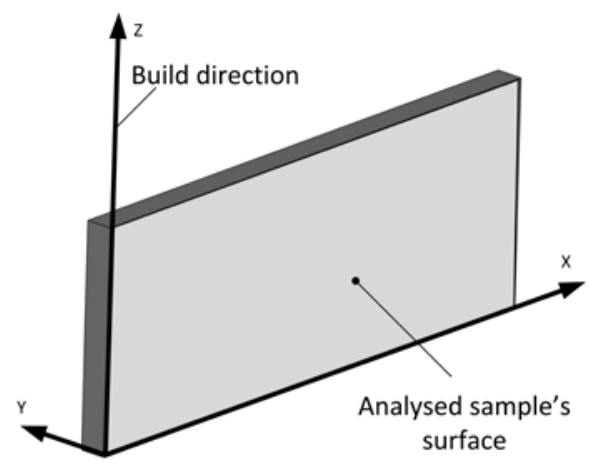

Fig. 1. View of the analysed surface of the SLM manufactured sample Rys. 1. Analizowana powierzania próbki wytwarzanej metodą SLM

Table I. Results of the substrate average roughness analyses before coatings depositing

Tablica I. Wyniki analizy średnich wartości chropowatości przed nałożeniem powłoki

\begin{tabular}{|c|c|c|}
\hline Type of sample surface & $\begin{array}{c}\text { Grit-blasting } \\
\text { parameter } \\
\mathrm{Al}_{2} \mathrm{O}_{3} \text { feeding } \\
\text { preassure, MPa }\end{array}$ & $\begin{array}{c}\text { Average values } \\
\text { of roughness } \\
\text { parameters } \mathrm{Ra} \\
\mu \mathrm{m}\end{array}$ \\
\hline Unmachined surfaces & - & 15,2509 \\
\hline Grit blasted surface, set no. 1 & 0,4 & 10,5504 \\
\hline Grit blasted surface, set no. 2 & 0,5 & 8,58285 \\
\hline Grit blasted surface, set no. 3 & 0,6 & 14,2604 \\
\hline
\end{tabular}

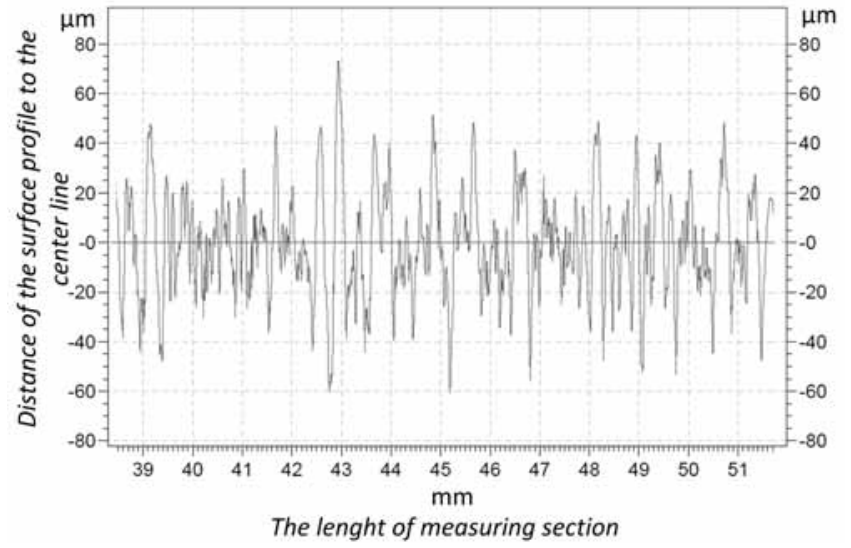

Fig. 2. Profilogram of the unmachined sample surface

Rys. 2. Profil nieobrobionej powierzchni próbki

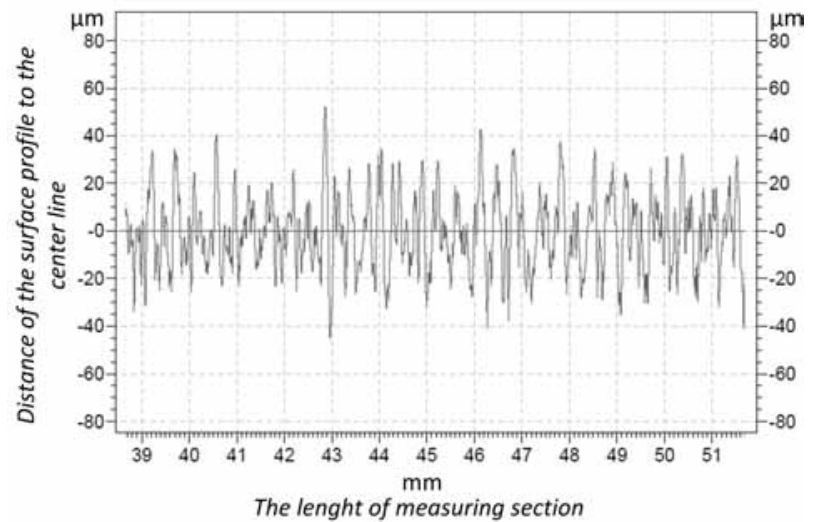

Fig. 3. Profilogram of the grit-blasted sample surface. Feeding pressure of $0,6 \mathrm{MPa}$

Rys. 3. Profil obrobionej strumieniowo powierzchni próbki. Ciśnienie wejściowe 0,6 MPa

on the geometrical structure of the substrate. Roughness analysis of the surfaces was performed using the Rank Taylor Hobson Form Talysurf 1201 profilographometer. Example results of the measurements for nonmachined surfaces have been presented in Fig. 2, and for the grit-blasted ones in Fig. 3.

In addition, an analysis of surface roughness was performed using the LEXT OLS4000 confocal microscope.

Results of the analyses of substrate surface not subjected to grit-blasting processing have shown that they are characterised with a structure containing non-melted powder grains. They adhere to the melted surfaces of the samples during the selective laser melting process. Character of the non-machined SLM surface may be observed in Fig. 4. Diameters values of the non-melted grains, ranging from several to about $70 \mu \mathrm{m}$, lead to high surface roughness of the SLM manufactured objects. Results of the roughness measurements carried out on the grit-blasted surfaces shows decreasing values of the Ra parameter, on average from above $15,25 \mu \mathrm{m}$ up to about $8,58 \mu \mathrm{m}$, as shown in Fig. 3. Character of the Ra changes can be explained as a result of removal of the non-melted powder grains partly agglomerated with the surface. Increasing of roughness for the third set of samples, 

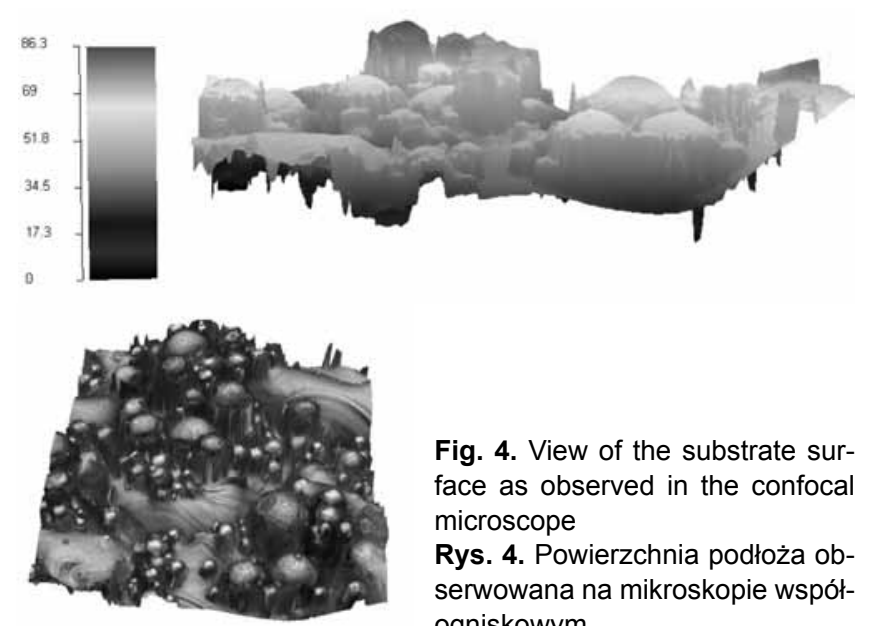

Fig. 4. View of the substrate surface as observed in the confocal microscope

Rys. 4. Powierzchnia podłoża obserwowana na mikroskopie współogniskowym

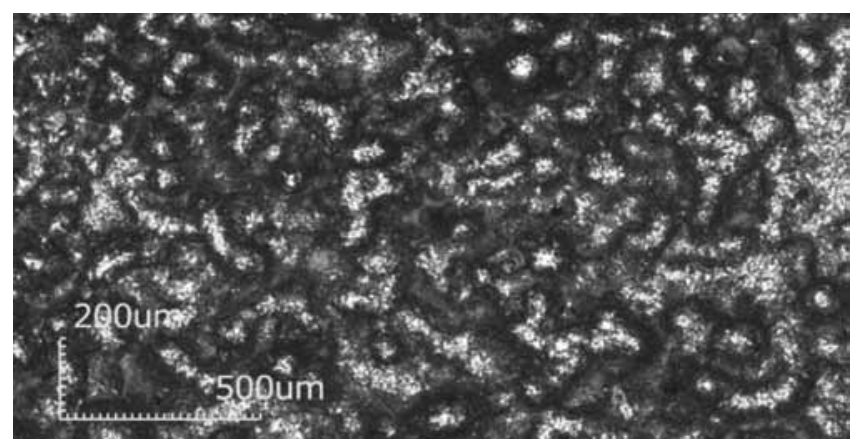

Fig. 5. View of the substrate surface after grit-blasting with $0,5 \mathrm{MPa}$ feeding pressure

Rys. 5. Powierzchnia podłoża obrobiona strumieniowo przy ciśnieniu wejściowym 0,5 MPa

which was processed with $0,6 \mathrm{MPa}$ feeding pressure, can be linked to the higher energy of the abrasive material stream and should be investigated in the further research. Microscopic view of the grit-blasted surface has been presented in Fig. 5 .

Results of the surface roughness analyses have been collected in Table I.

\section{Coating deposition}

Coatings were sprayed by the APS $60 \mathrm{~kW}$ robotised plasma spraying system equipped with the BayState Surface Tech SG100 plasma burner. Sample coatings were deposited with parameters presented in Table II.

The second stage of investigations was analyses of the internal structure with the using of the industrial tomography method (CT). It was carried out by the Zeiss Metrotom CT equipment with a detector of $1024 \times 1024$ pixels resolution and the $225 \mathrm{kV}$ lamp enabling achievement of $10 \mu \mathrm{m}$ measurements resolution. The CT tests enabled determining porosity of the deposited coatings. Exemplary result of porosity analysis for coating deposited on the grit-blasted surface, has been presented in Fig. 6 . It was characterised with banding location of the pores resulting from the coating deposition process. Subsequent layers of the deposited
Table II. Parameters of plasma burner operation during test coatings deposition

Tablica II. Parametry procesu podczas natryskiwania powłok próbnych

\begin{tabular}{|c|c|c|c|}
\hline \multicolumn{2}{|c|}{ Current } & \multicolumn{2}{c|}{ Gases } \\
\hline Voltage, $\mathrm{V}$ & Intensity, A & Ar flow, l/min & He flow, I/min \\
\hline 40 & 450 & 66 & 14 \\
\hline
\end{tabular}

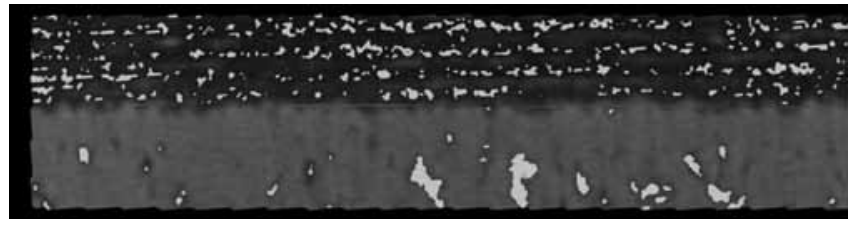

Fig. 6. Example of CT image of the coating (top) and substrate (bottom) porosity. Coating deposited on the grit-blasted substrate

Rys. 6. Przykład obrazu CT porowatości powłoki (u góry) i podłoża (u dołu). Powłoka naniesiona na obrobione strumieniowo podłoże

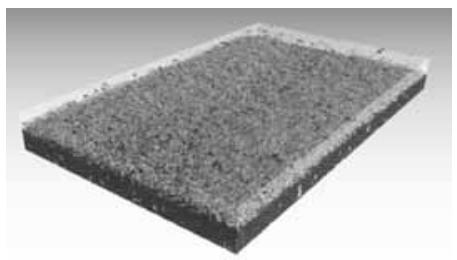

Fig. 7. View of spatial qualitative analysis of arrangement and morphology of the coating discontinuity

Rys. 7. Jakościowa analiza przestrzenna rozmieszczenia morfologii nieciągłości powłoki
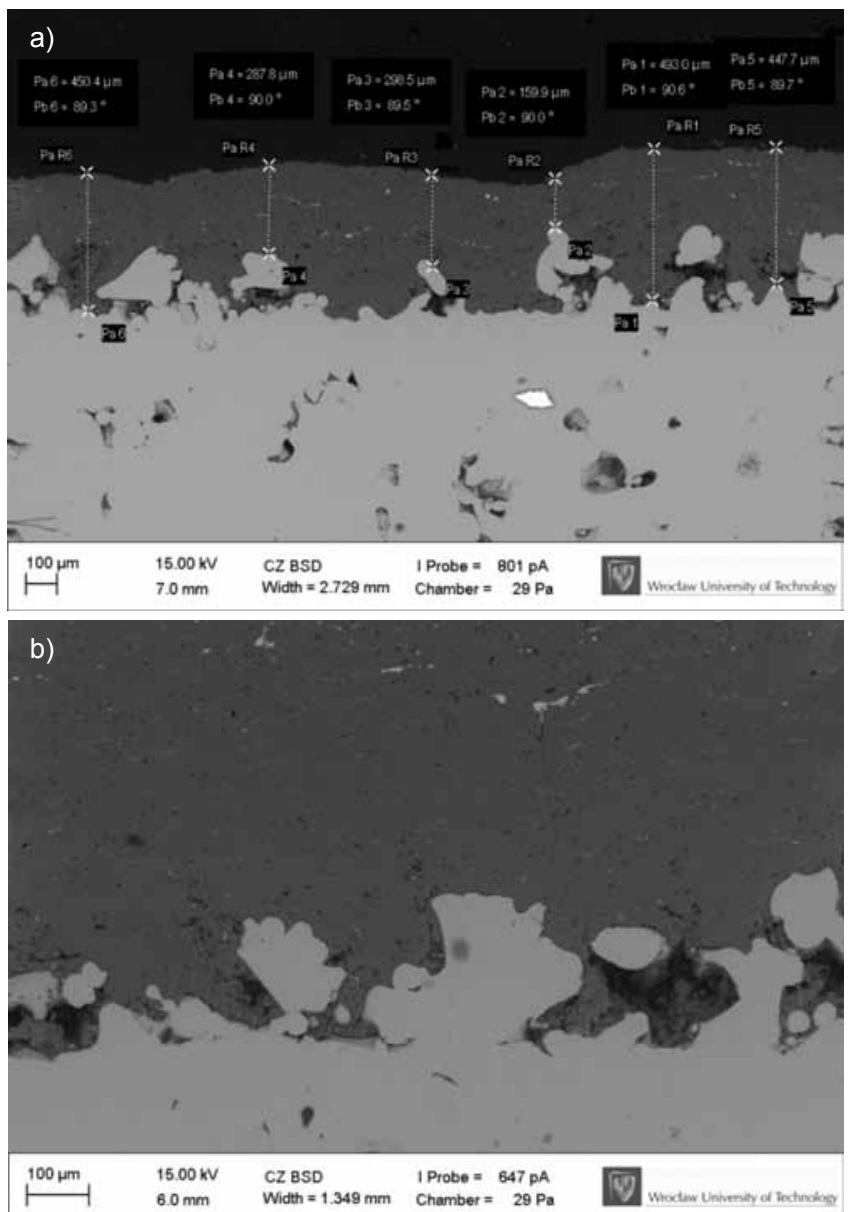

Fig. 8. Example of SEM images of the coating (top) and substrate (bottom) cross-section: a) overall view with coating thickness marked, b) detailed view of the coating pores. Coating deposited at the non-machined substrate

Rys. 8. Przykładowe obrazy SEM przekroju powłoki (u góry) i podłoża (u dołu): a) widok całej grubości powłoki, b) powiększenie obszaru z porowatością powłoki. Powłoka nanoszona na nieobrobione podłoże 


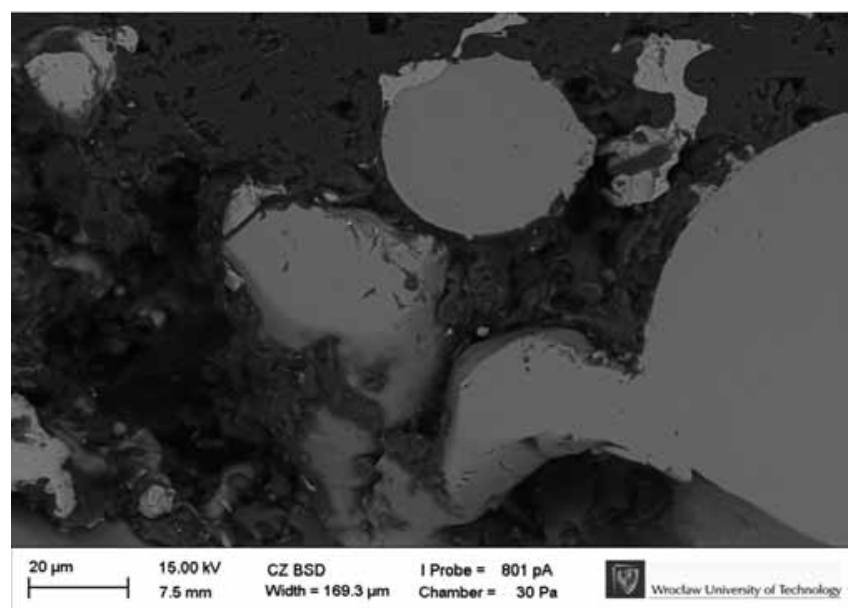

Fig. 9. SEM image of defects in the $\mathrm{Al}_{2} \mathrm{O}_{3} / \mathrm{TiO}_{2}$ coating resulting from complex structure of the substrate surface. Coating deposited at the non-machined substrate

Fig. 9. Obraz SEM wad w powłoce $\mathrm{Al}_{2} \mathrm{O}_{3} / \mathrm{TiO}_{2}$ wynikających ze złożonej struktury podłoża. Powłoka nanoszona na nieobrobione podłoże

coating were separated by bands of pores. Fig. 6 presents the pore bands located in 4 layers between 5 deposited layers of the coating. It was not observed pores on the layer between the substrate and the coating, which allowed assumption on its high adherence to the substrate. The results of porosity analysis for coatings deposited on the non-machined substrates, showed discontinuity of the coating on the layer between coating and substrate.

Also, porosity of the coated substrate has been observed, as seen in Fig. 6, that is characteristic for substrates manufactured with the SLM method. Size and arrangement of the pores could be parameters, the values of which are controlled by selecting the proper parameters for the selective laser melting process, involving, among others, the laser power and scanning rate of the layer fused with a laser beam [1].

CT analysis results have been verified by SEM tests, performed at transverse microsections of the samples with deposited coatings. Measurements

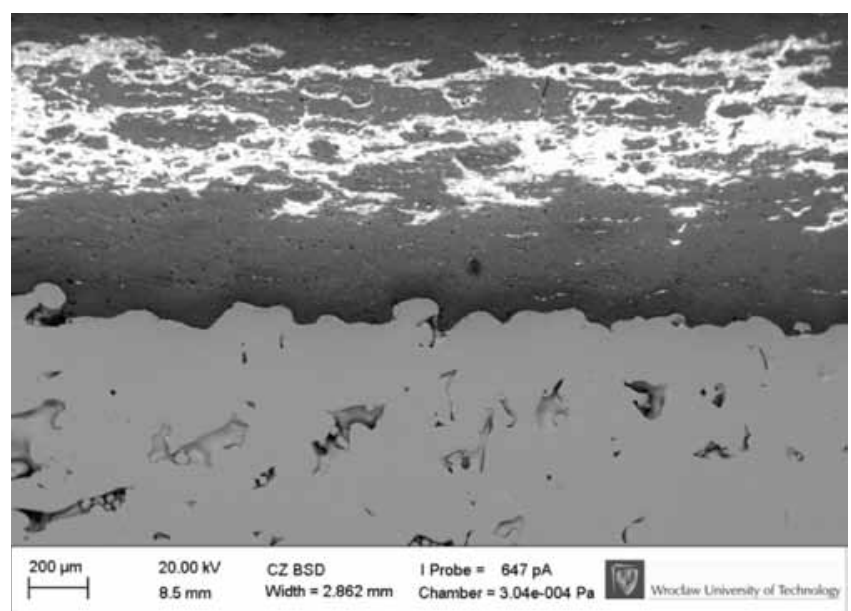

Fig. 10. Example SEM image of coating (top) deposited at grit-blasted substrate (bottom)

Rys. 10. Przykładowy obraz SEM powłoki (u góry) nanoszonej na obrobione podłoże (u dołu)

of coating thicknesses were performed at them, which have shown similar values amounting to about $450 \mu \mathrm{m}$.

The coating structure discontinuities observed during $C T$ analysis, corresponded to its defects found during analysis using SEM, see Fig. 8 and Fig. 9. Their presence could be related to the complex geometrical surfaces structure of substrates manufactured with the SLM. The non-melted Ti6Al7Nb powder grains agglomerated to its surface could prevent correct deposition of coating at the whole substrate surface, which is visible in Fig. 9. In the SEM images of the cross-sections of coating samples deposited at gritblasted substrates much lower number of coating defects was observed at the junction with the substrate surface, see Fig. 10 . The observed regularity results from removal of the Ti6Al7Nb powder grains weakly bound with the substrate by means of grit-blasting, which resulted in better adhesion of the coating, as seen on Fig. 10.

\section{Literature}

[1] Chlebus E., Kuźnicka B., Kurzynowski T., Dybała B.: Microstructure and mechanical behaviour of Ti-6Al-7Nb alloy produced by selective laser melting, Materials Characterization 62 , 2011, s. 488-495.

[2] Chlebus E.: Rapid prototyping and advanced manufacturing Springer handbook of mechanical engineering / [Karl-Heinrich] Grote, [Erik K.] Antonsson (eds.). Berlin: Springer, 2009, s. 733-768.

[3] Frankiewicz M., Kurzynowski T., Dybała B., Chlebus E.: Rapid Tooling application in manufacturing of injection moulds, Virtual design and automation/ed. by Z. Weiss. Poznań : Publishing House of Poznan University of Technology, 2008. s. 155-162.

[4] Heinmann R.: Plasma Spray Coating, John Wiley \& Sons, Ltd, Chichester, UK, 2008.

[5] Pawlowski L.: The Science and Engineering of Thermal Spray Coatings, John Wiley \& Sons, Ltd, Chichester, UK, 2008.
[6] Rico A., Poza P., Rodríguez J.: High temperature tribological behavior of nanostructured and conventional plasma sprayed alumina-titania coatings, Vacuum, Available online 2 March 2012, ISSN 0042-207X.

[7] Venkataraman R., Gautam Das a, Venkataraman B., Narashima Rao G.V., Krishnamurthy R.: Image processing and statistical analysis of microstructures of as plasma sprayed Alumina-13 wt. \% Titania coatings, Surface \& Coatings Technology 201, 2006, s. 3691-3700.

[8] Yugeswaran S., Selvarajan V., Vijay M., Ananthapadmanabhan P.V., SreekumarK.P.: Influence of critical plasma spraying parameter (CPSP) on plasma sprayed Alumina-Titania composite coatings, Ceramics International 36, 2010, s. 141149. 